CUADERNOS DE ESTUDIOS GALLEGOS, LIX Núm. 125 (enero-diciembre 2012), págs. 115-142

ISSN: 0210-847 X

DOI: 10.3989/ceg.2012.125.05

\title{
O TOMBO DE 1560/1565 DA GRANJA DA SILVA DO MOSTEIRO DE SANTA MARIA DE OIA. ASPECTOS DA EVOLUÇÃO E CONSOLIDAÇÃO DO PATRIMÓNIO MEDIEVAL DO MOSTEIRO DE OIA NO ENTRE-LIMA-E-MINHO PORTUGUÊS ATRAVÉS DA ANÁLISE DE UM DOCUMENTO DE ÉPOCA MODERNA
}

\author{
Ana Paula Leite Rodrigues* \\ Universidade de Santiago de Compostela \\ Instituto de Estudos Medievais \\ Faculdade de Ciências Sociais e Humanas \\ Universidade Nova de Lisboa
}

\footnotetext{
* Bolseira de doutoramento da Fundação para a Ciência e Tecnologia.
} 
O TOMBO DE 1560/1565 DA GRANJA DA SILVA DO MOSTEIRO DE SANTA MARIA DE OIA. ASPECTOS DA EVOLUÇÃO E CONSOLIDAÇÃO DO PATRIMÓNIO MEDIEVAL DO MOSTEIRO DE OIA NO ENTRE-LIMA-E-MINHO PORTUGUÊS ATRAVÉS DA ANÁLISE DE UM DOCUMENTO DE ÉPOCA MODERNA

\section{RESUMO}

O mosteiro de Santa Maria de Oia, situado na costa do sudoeste da província de Pontevedra, entre as localidades de Baiona e A Guarda, representa um excelente objecto de investigação no âmbito do estudo da fronteira medieval entre a Galiza e o Entre-Lima-e-Minho português. Desde os primórdios da sua fundação, o mosteiro de Oia possuiu propriedades em Portugal. Uma eficaz e cautelosa gestão patrimonial, em consonância com a tradição cisterciense, possibilitou a multiplicação dos seus bens no território português e a sua concentração em dois núcleos principais: a Granja da Silva, que agrupava todas as possessões do Noroeste de Portugal, e o conjunto dos bens situados em Lisboa e no termo de Torres Vedras. A reflexão que de seguida apresentamos incide sobre parte das propriedades do primeiro núcleo, em concreto as inventariadas ao longo do Tombo da Granja da Silva de 1560/1565. No âmbito da investigação de doutoramento que actualmente levamos a cabo, sobre a projecção económica e social do senhorio de Oia em Portugal na Idade Média, tentaremos averiguar quais os principais contributos que o tombo pode oferecer enquanto expressão ad quem da evolução de um património que, formando-se e consolidando-se na época medieval, persevera durante a época moderna.

PAlaVRAS ChaVE: Mosteiro de Oia/Granja da Silva, evolução patrimonial, organização social do espaço rural, perspectiva ad quem, fronteira Galaico-Portuguesa, História comparativa.

\section{EL TUMBO DE 1560/1565 DE LA GRANJA DA SILVA DEL MONASTERIO DE SANTA MARÍA DE OIA. ASPECTOS DE LA EVOLUCIÓN Y CONSOLIDACIÓN DEL PATRIMONIO MEDIEVAL DEL MONASTERIO DE OIA EN EL ENTRE-LIMA-E-MINHO PORTUGUÊS A TRAVÉS DEL ANÁLISIS DE UN DOCUMENTO DE ÉPOCA MODERNA}

\section{RESUMEN}

El monasterio de Santa María de Oia, situado en la costa del sudoeste de la provincia de Pontevedra, entre Baiona y A Guarda, representa un excelente objeto de investigación en el ámbito del estudio de la frontera medieval entre Galicia y la región portuguesa delimitada por los ríos Límia y Miño. Desde sus comienzos, la abadía de Oia contó con propiedades en Portugal. Una eficaz y cautelosa gestión patrimonial, en conformidad con la tradición cisterciense, conllevó a la multiplicación de los bienes del territorio portugués, bien como a la concentración de los mismos en dos núcleos principales: la Granja da Silva, que reunía todas las posesiones del noroeste de Portugal, y el conjunto de los bienes situados en Lisboa y en el término de Torres Vedras. La reflexión que a continuación presentamos se centrará en parte de las propiedades referidas al primer núcleo, concretamente las que se incluyen en el Tumbo de la Granja de la Silva de 1560/1565. En el marco de nuestra tesis doctoral centrada en el análisis de la proyección económica y social del señorío de Oia en Portugal en la Edad Media, trataremos de averiguar cuáles son las principales aportaciones que nos puede ofrecer el Tumbo en cuanto expresión ad quem de la evolución de un patrimonio que, formándose y consolidándose en la época medieval, se prolonga durante la Edad Moderna.

PAlABRAS ClAVE: Monasterio de Oia/Granja de la Silva, evolución patrimonial, organización social del espacio rural, perspectiva ad quem, frontera Galaico-Portuguesa, Historia comparativa.

\section{THE TOMBO DA GRANJA DA SILVA (1560/1565) OF THE MONASTERY OF SANTA MARIA DE OIA. ASPECTS OF THE EVOLUTION AND CONSOLIDATION OF OIA'S MEDIEVAL PATRIMONY IN NORTHWEST PORTUGAL THROUGHT THE STUDY OF A MODERN AGE DOCUMENT}

\section{ABSTRACT}

The monastery of Santa Maria de Oia, located on the southwestern coast of Pontevedra province, between Baiona and A Guarda, provides us an excellent subject to the investigation of the medieval Galician and northwest Portuguese border. Oia's abbey owned properties in Portugal since the very begging of its foundation. The efficient and cautious management of its acreage, in accordance with the Cistercian tradition, made possible to the monastery to multiply the number of its properties in Portugal and to organize them into two main groups: the one of the Granja da Silva, which integrated all the possessions in the northwest territory, and the other one including properties in Lisbon and Torres Vedras. The first of those main groups is the subject of the Tombo da Granja da Silva (1560/1565), a document in which are recorded almost all the properties of Oia's monastery. The aim of this text is to evaluate all the possible contributions the tombo may offers to the research of Oia's medieval patrimony in Portugal, as a terminus ad quem of its evolution through the Middle Ages until the XVIth century. KEY WORDS: Monastery of Oia/Granja da Silva, patrimonial evolution, rural space social organization, ad quem perspective, Galician-Portuguese frontier, comparative History. 
Recibido/Received: 07/02/2012

Aceptado/Accepted: 14/08/2012

$\mathrm{N}$

o Tumbo de los bienes y propiedades que tiene el monasterio cisterciense de Santa María de Oya, Pontevedra, en la Granja de la Silva y de los bienes a ella anejos, en el Reino de Portugal ${ }^{1}$ encontramos o registo exaustivo de um inquérito efectuado aos foreiros e moradores de diversas freguesias integrantes da Granja da Silva nos anos de 1560 e 1565. A transcrição, e posterior análise, dos resultados dos muitos depoimentos prestados constituiu a base do nosso Traballo de Investigación Tutelado ${ }^{2}$, elaborado no contexto das exigências académicas inerentes ao último ano da etapa de formação do programa de doutoramento Economía e Sociedade na Historia: Épocas Medieval e Moderna, da Faculdade de Xeografía e Historia da Universidade de Santiago de Compostela. No contexto do projecto de doutoramento que, desde 2008, levamos a cabo no departamento de História Medieval e Moderna da USC, podemos definir este trabalho com um primeiro ensaio de investigação sobre a projecção económica e social do mosteiro de Oia, enquanto instituição senhorial, no território português, durante o período medieval.

Logo a priori, parece contraditória e pouco adequada a relação estabelecida entre o estudo dos resultados de um inquérito efectuado na segunda metade do século XVI e os objectivos de um projecto de tese de doutoramento em História medieval em que esse mesmo estudo se pretende inserir. Porquê iniciar o cami-

\footnotetext{
${ }^{1}$ Archivo Historico Nacional (doravante AHN), Códices, L.1037. Para este trabalho o documento foi consultado na sua versão digitalizada: Ministerio De Cultura, Portal de Archivos Españoles (PARES) [na rede], disponível em <http://pares.mcu.es/> [Consulta: 01/01/2010 e 6/1/2012], (doravante, a fim de facilitar a leitura e compreensão do texto, recorreremos à seguinte fórmula abreviada para citar este tombo: AHN, Códices, L.1037).

2 Ana Paula Rodrigues, O Tombo da Granja da Silva (1560/1565). Bases para uma análise da propriedade transfronteiriça do Mosteiro de Santa Maria de Oia. Traballo de Investigación Tutelado apresentado em Julho de 2010, perante o tribunal composto pelos Professores Doutores Amélia Aguiar Andrade, Pegerto Saavedra Fernández e José Miguel Andrade Cernadas, e avaliado com a classificação de Sobresaliente (10 valores), na Facultade de Xeografía e Historia da USC com vista à obtenção do Diploma de Estudios Avanzados. Inédito.
} 
nho da investigação do senhorio medieval de Oia em Portugal a partir da análise de um documento do século XVI? De que forma pode esta fonte constituir, no caso particular da Granja da Silva, um contributo válido para o estudo da evolução deste núcleo de propriedades ao longo da Idade Média? As respostas que procuraremos dar a estas perguntas serão, precisamente, o fio condutor deste texto.

A eleição do património medieval transfronteiriço do mosteiro de Oia como objecto de trabalho foi, em grande medida, originada por um interesse pessoal sobre a evolução das relações económicas, sociais e políticas entre o Norte de Portugal e a Galiza, particularmente, aquelas que durante a época medieval moldaram, como mais adiante veremos, vários aspectos do quotidiano da população rural e camponesa. Neste sentido, atrevemo-nos a afirmar que o mosteiro de Oia constitui um caso paradigmático (embora não excepcional ${ }^{3}$ ) e, consequentemente, idóneo para o estudo da sociedade e economia da zona raiana do Noroeste peninsular. A extensão e importância económica das suas possessões no território português, bem como o conjunto populacional sobre o qual recaía o seu poder, convertem Oia num excelente tema de estudo e investigação.

Alguns dos estudos mais recentes sobre o mosteiro de Oia alertam-nos para a grande dificuldade encontrada no momento de apontar uma data exacta para a fundação deste cenóbio ${ }^{4}$. Contudo, a documentação permite-nos saber que os

\footnotetext{
3 Apenas a título de exemplo, e porque um levantamento exaustivo de todas as instituições senhoriais eclesiásticas proprietárias de bens em ambos os lados do rio Minho não se adequa aos propósitos deste texto, citamos os casos do Cabido e Mitra de Tui e do mosteiro português de Fiães, sugeridos por José Marques, e os de Santa Maria de Tomiño de S. Domingos de Tui apontados por Ernesto Iglesias Almeida. De facto, e apesar da imposição da fronteira política no século XII (cuja vigilância se revelou por vezes assaz rigorosa) e da delimitação da diocese de Tui pela linha do Minho operada nos finais do século XIV, as relações entre as populações raianas pautaram-se pelos padrões da boa convivência e vizinhança. Neste cenário das relações galaico-minhotas, as instituições eclesiásticas - monásticas e seculares - sediadas de um e outro lado da fronteira, desempenharam uma função de alto relevo, aliás correspondente à sua importância sócio-económica e religiosa, com forte impacto nas populações circundantes (pág. 206) José MARQUEs, "O mosteiro de Oia e a Granja da Silva, no contexto das relações luso-castelhanas dos séculos XIV-XV", em Relações entre Portugal e Castela nos finais da Idade Média, s. 1., Fundação Calouste Gulbenkian, Junta Nacional de Investigação Científica e Tecnológica, 1994, págs. 205-206. Ernesto IgLesias Almeida, O antiguo obispado de Tui en Portugal, Noia, Editorial Toxosoutos, 2009, págs. 95-100. Relativamente às características fundamentais e evolução das relações políticas e sociais da fronteira entre a Galiza o Entre-Lima-e-Minho no transcurso da época medieval veja-se também Amélia Aguiar ANDRADE, "Entre Lima e Minho na Idade Média: uma relação de amor e ódio", em Carlos Alberto Ferreira de Almeida: in memoriam, vol. I, Porto, Faculdade de Letras da Universidade do Porto, 1999, págs. 77-92.

${ }^{4}$ Vejam-se, por exemplo: $M^{a}$ del Carmen Pallares Mendez e Ermelindo Portela Silva, El Bajo Valle del Miño en los siglos XII y XIII. Economía agraria y estructura social, Santiago de Compostela, Universidade de Santiago de Compostela, 1971, págs. 69-134; Marta CENDÓN FERNÁNDEZ,
} 
primórdios do mosteiro de Oia e a possessão de bens e propriedades em território português foram realidades coevas. Em Agosto de 1145, o monge Paio Guterres, membro da comunidade de Oia, doa ao mosteiro três casais em Verdoejo (actual concelho de Valença do Minho) e parte de uma herdade em Mozelos (Paredes de Coura), a qual lhe fora doada por Dona Teresa, em reconhecimento dos serviços prestados e, posteriormente, confirmada pelo rei D. Afonso Henriques ${ }^{5}$. De acordo com a opinião manifestada por Ermelindo Portela Silva, esta doação representa mesmo a primeira referência documental autêntica ao mosteiro de Oia enquanto tal, isto é, uma comunidade religiosa estabelecida no lugar de Oia ${ }^{6}$.

A leitura da documentação medieval de Oia permite-nos comprovar que a doação do monge Paio Guterres foi apenas o início de um percurso de incremento e consolidação do património de Oia em Portugal. Ao longo da Idade Média, sobretudo durante os séculos XIII e XIV, o mosteiro de Oia foi reunindo um conjunto considerável de bens em território português, graças a doações, compras e escambos que, aliadas a uma gestão prudente e eficaz do património, possibilitaram a formação de dois núcleos principais de propriedades. O núcleo situado na região da Estremadura portuguesa, que incluía bens nos termos de Lisboa e Torres Vedras e, o mais importante, correspondente à Granja da Silva, cabeça e celeyro de todollos beens de Antre Limha e Minho ${ }^{7}$.

Estamos assim perante um senhorio monástico galego que, no decorrer da Idade Média é proprietário de um amplo conjunto de bens em território português, concentrados em dois núcleos principais, distantes entre si. Partindo desta realidade, as linhas de uma investigação doutoral poderiam ser diversas e os possíveis enfoques variados. No nosso caso, optamos por nos debruçar sobre os

\footnotetext{
"Santa María de Oia”, em Fray M Mamián Yáñez Neira (coord.), Monasticón cisterciense gallego, vol. 1, León, 2000, págs. 198-223; Ermelindo Portela SiLVA, "En torno a los orígenes del monasterio de Santa María de Oia. Císter en la frontera galaicoportuguesa.”, em III Seminário Internacional Tarouca e Cister, Tarouca, 2010 (no prelo).

5 AHN, Clero, Oya, carp. 1794, doc. 7. E. Portela Silva, "En torno a los orígenes...”, págs. 4, 6, 14 e 20.

${ }^{6} \mathrm{O}$ autor põe assim em causa a veracidade das datas dos quatro documentos referentes ao mosteiro de Oia atribuídos à chancelaria de Afonso VII que, por erro no momento da cópia ou de forma intencional, surgem como anteriores ao da doação referida. Quanto à doação de parte dos direitos eclesiásticos da ecclesiola de São Mamede de Loureza feita pelo bispo Paio de Tui ao abade Pedro, quatro meses antes da doação de Paio Guterres, Ermelindo Portela alerta para o facto de que na mesma se alude à villa e não ao mosteiro de Oia, considerando, portanto que (...) no parece que exista en Oia monasterio alguno; el lugar, por el momento, es definido como villa, esto es, un espacio habitado seguramente desde hacía mucho tiempo, cuya propiedad ha sido transferida a los cenobitas recientemente instalados en Loureza. (págs. 5-6). E. Portela SiLva, "En torno a los orígenes...", págs. 3-6. Documentos em AHN, Clero, Oya, carp. 1794, docs. 2, 4, 5, 6 e 7.

${ }^{7}$ AHN, Clero, Oya, carp. 1827, doc. 17. Transcrição em J. MARques, "O mosteiro de Oia e a Granja da Silva...", págs. 222-224.
} 
principais aspectos económicos e sociais que davam forma às relações estabelecidas entre o mosteiro - o senhor - e o conjunto da população, maioritariamente rural, integrada nos dois núcleos de propriedades - os dependentes. Simultaneamente decidimos reflectir sobre o quadro político em que estes vínculos se inseriam, tentando precisar os principais aspectos da relação entre o mosteiro, enquanto senhorio transfronteiriço, com os dois grandes poderes políticos que governavam os territórios das suas possessões: as Coroas de Portugal e Castela.

\section{ApresentaÇão da FONTE: OS TEXTOS INICIAIS}

O estudo da evolução do senhorio de Oia em Portugal entre os séculos XII e XV implica, obviamente, a utilização e análise escrupulosa do conjunto dos pergaminhos de época medieval ${ }^{8}$ do mosteiro, enquanto corpus documental básico e primordial que, ao mesmo tempo, é responsável pela delimitação cronológica da nossa investigação. Contudo, o trabalho de heurística desenvolvido no Archivo Historico Nacional, tanto o realizado através do sítio do Portal de Archivos Españoles $^{9}$ na rede, como o que levamos a cabo in loco, revelou-nos a existência de um abundante e rico conjunto de documentação de época moderna referente ao senhorio do mosteiro de Oia em Portugal. De entre estes documentos, merecem destaque os vários tombos de propriedades referentes especificamente ao património da Granja da Silva, como o já citado códice de 1560/1565 e os outros dois datados dos séculos XVII (1601) e XVIII (1749) ${ }^{10}$, bem como a colecção dos Legajos, cuja secção 4 do n ${ }^{\circ} 5471$ inclui também um pequeno rol de propriedades, que o mosteiro de Oia possuía em Paredes de Coura, datado de $1593^{11}$.

A informação que nos oferece a documentação de época moderna obviamente ultrapassa o terminus ad quem do nosso projecto de investigação. Todavia estes tumbos e apeos da Granja da Silva, ao constituírem um conjunto organizado de descrições de propriedades, podem ser de grande utilidade na medida em que possibilitam reconstituir um mapa mais objectivo e preciso da distribuição geográfica das propriedades da Granja da Silva, tal como do tipo de organização patrimonial do espaço rural e agrícola correspondente. A minuciosidade destes documentos inclui múltiplas e detalhadas referências aos limites e confrontações dos vários terrenos e propriedades, ao valor e pagamento de rendas e tributos, assim como a determinados aspectos relacionados com os contratos enfitêuticos

\footnotetext{
${ }^{8}$ AHN, Clero, Oya, carpetas 1794 a 1854.

9 Ministerio de Cultura, Portal de Archivos Españoles (PARES) [na rede], disponível em <http:// pares.mcu.es/> [Consulta: 6/1/2012].

${ }^{10}$ AHN, Códices, L.1037, L. 1036, L. 1035, consultados em: Ministerio de Cultura, Portal de Archivos Españoles (PARES) [na rede], disponível em <http://pares.mcu.es/> [Consulta: 6/1/2012].

${ }^{11}$ AHN, Legajos, $5471, \mathrm{n}^{\circ} 4$.
} 
e seus intervenientes. Muitos destes elementos constituintes da realidade de um senhorio não podem, naturalmente, ser transpostos para um contexto medieval, pois seria crasso e inadmissível o anacronismo que tal situação comportaria. Contudo, e dada a disponibilidade da documentação de época moderna, caso nem sempre frequente no estudo do património senhorial de instituições monásticas, ou de outras, pareceu-nos essencial a consulta destas fontes. De facto, o património do mosteiro de Oia em território português, particularmente a Granja da Silva, assim como o modelo de organização das propriedades, forja-se na época medieval mas prolonga-se durante a Idade Moderna. A consulta e possível utilização de alguma da informação fornecida por estes códices de época moderna no nosso projecto de tese pretende sobretudo elucidar-nos sobre alguns dos aspectos desta evolução patrimonial. Pretende, como veremos mais adiante, revelar alguns dos matizes, ou referências mais pontuais, de uma herança medieval.

Uma vez expostos os principais aspectos de um possível contributo decorrente do confrontação da informação contida nas fontes de época moderna e o corpus documental medieval para estudo do património de Oia na Granja da Silva, tentaremos agora concretizar este argumento através da apresentação formal do Tumbo de los bienes y propiedades de la Granja de la Silva e, posteriormente, de alguns dos seus conteúdos.

Apesar dos duzentos e trinta e três fólios que compõem este documento serem, na sua maioria, um traslado de 1579 , o seu conteúdo é o resultado do exaustivo inquérito feito aos foreiros da Granja da Silva nos anos de 1560 e $1565^{12}$. Tratando-se de um tombo de bens e propriedades, a descrição das dimensões, localização e tipologia dos bens e propriedades que o mosteiro de Oia possuía na Granja da Silva constitui o fundamental da informação contida no documento, à qual se acrescentam outros tipos de referências relacionadas com os quantitativos de produtividade dos terrenos agrícolas, o valor e tipo de determinadas rendas e foros, a identidade e número de foreiros, e ainda algumas características dos contratos de emprazamento. Este detalhado inventário é precedido por uma série de textos preliminares que ocupam os dezoito primeiros fólios do códice e que nos fornecem um conjunto de informações imprescindíveis para a compreensão dos motivos que originaram este inquérito, assim como do contexto histórico em que se enquadra.

\footnotetext{
${ }^{12}$ A inquirição aos bens da Granja da Silva efectua-se em dois momentos diferenciados: o primeiro que vai desde os finais de Fevereiro de 1560 até o dia 8 de Março do mesmo ano, e o segundo de 22 de Março a 9 de Junho de 1565. À mudança de ano, registada a partir do fol. 104, junta-se a referência a um novo juiz de fora de Monção, responsável pelos trabalhos de averiguação, surgindo assim o nome do juiz Pedro Borges como substituto do seu homólogo Tomé Álvares. O documento não apresenta, no entanto, qualquer razão justificativa destas duas alterações.
} 
O primeiro destes textos preliminares deve ser entendido como uma introdução ou apresentação do conteúdo do próprio tombo da Granja da Silva. Nele são enumeradas as freguesias onde se localizam as principais possessões do mosteiro de Oia: Santa Maria e São Julião da Silva, São Miguel de Fontoura, Cerdal, Valença, São Pedro da Torre (no actual concelho de Valença do Minho) e Vila Meã, Campos, Cornes, Vila Nova de Cerveira e São Pedro de Gondarém, pertencentes ao actual concelho de Vila Nova de Cerveira [Mapa 1]. Paralelamente, revela-nos também os limites cronológicos da execução do inquérito, iniciado no ano de 1560 durante o abaciado de frei Prudêncio de la Fuente ${ }^{13}$, e terminado em 1565, bem como a identidade dos responsáveis pela tarefa de recolher e registar por escrito os depoimentos dos foreiros da granja: o licenciado Tomé Álvares, juiz de fora de Monção e António Pais Rebelo, tabelião público e judicial do Rei na mesma vila ${ }^{14}$.

Segue-se a este pequeno texto introdutório sobre os principais conteúdos deste tombo, um índice que nos permite averiguar a distribuição das propriedades da Granja da Silva pelas diferentes freguesias. Embora não exista uma correspondência exacta entre este e o conteúdo da fonte, devido sobretudo às lacunas que o primeiro apresenta, a relação entre as freguesias e as principais propriedades serve de orientação no momento de as localizar geograficamente e de avaliar a distribuição do número de bens correspondente a cada uma delas. Assim, por exemplo, a simples leitura deste índice denota, a priori, a preponderância da freguesia de Santa Maria da Silva sobre as demais. A própria designação de Granja da Silva, assim como a de Quintã da Fradeira, fazem alusão directa ao carácter

\footnotetext{
${ }^{13}$ No corpo deste primeiro texto introdutório, Fernando de Salinas aparece referido como sendo o abade de Oia à data do início do inquérito; contudo, em cima do nome deste abade, uma pequena anotação sugere que, em realidade, era frei Prudêncio de la Fuente quem, então, ocupava o cargo. No tombo, Frei Prudêncio surge por várias vezes referido como o representante do mosteiro no decorrer do questionário efectuado a vários dos foreiros da Granja da Silva. Por isso, consideramos que a referência ao abaciado de Fernando de Salinas é um equívoco que a pequena anotação indicada pretenderia corrigir. AHN, Códices, L.1037, fols. 39, 51, 55 e 57.

${ }^{14}$ O último parágrafo deste texto introdutório faz ainda referência ao "tumbo nuevo que se hiço el ano de 1601" no qual "se appeo y averiguo mucha mas façienda que esta en este", em alusão ao já citado códice do século XVII (vide pág. 5). Desta forma, podemos saber que, apesar do carácter minucioso do inquérito de 1560/1565 este não incluiu a totalidade dos bens e propriedades que formavam o conjunto da Granja da Silva. De facto, o quadro-síntese das propriedades do mosteiro de Oia no Entre-Lima-e-Minho, apresentado por José Marques e elaborado, em parte, recorrendo a informação presente na documentação medieval, aponta também para a existência de bens noutras freguesias que não aquelas que nos são apontadas nesta introdução ao tombo. J. MARQUES, "O mosteiro de Oia e a Granja da Silva...”, pág. 209.
} 
central da freguesia de Santa Maria da Silva e, mesmo, a um dos seus lugares mais centrais ${ }^{15}$.

Os traslados que se seguem são ainda mais relevantes para a compreensão do documento, tanto em relação ao seu conteúdo como ao objectivo da sua elaboração. Ao não apresentarem uma sequência cronológica coerente, referiremos aqueles que consideramos mais cruciais de acordo com a evolução lógica dos acontecimentos e acções a que dizem respeito, de maneira a facilitar a sua compreensão.

A procuração de 11 de Julho de 1554, elaborada em nome dos religiosos do mosteiro de Oia, outorga ao abade, na altura frei Fernando de Salinas, ao prior frei Bento de Segóvia e ao celeireiro frei João Lemos o papel de procuradores do mosteiro. Tal poder concedia-lhes o estatuto de representantes legais do mosteiro em situações tão diversas como julgamentos, juramentos, cobrança de rendas e tributos, realização de compras e vendas de bens, estabelecimento de contratos de vária índole. Eram ainda os representantes do cenóbio perante qualquer autoridade, civil ou religiosa. Frei Bento de Segóvia assumiu o papel de procurador do mosteiro ao longo de praticamente todo o processo de inquirição, quer acompanhando os juízes de fora de Monção, primeiro Tomé Álvares e posteriormente Pêro Borges, e os medidores convocados para levar a cabo a delimitação das propriedades, quer estando presente aquando das declarações e juramentos dos foreiros ${ }^{16}$. Foi também o responsável pelas notificações feitas aos moradores e foreiros da Granja da Silva, a fim de testemunharem sobre a extensão e situação geográfica das propriedades, os foros a pagar e as condições dos contratos de emprazamento. Pode por isso afirmar-se que foi a voz das vontades e intenções do mosteiro de Oia.

Nomeado assim representante e procurador do mosteiro de $\mathrm{Oia}^{17}$, é frei Bento de Segóvia quem apresenta perante o monarca português o pedido de autorização para levar a cabo o inquérito da Granja da Silva, alegando que alguns dos

\footnotetext{
${ }^{15}$ Sobre a utilização das expressões Granja da Silva e Quintã da Fradeira reflectiremos mais adiante (vide pág. 23). Por agora cabe destacar que, ainda hoje em dia, ao percorrer a actual freguesia de Santa Maria da Silva, verificamos que Fradeira corresponde a um dos lugares centrais na sua geografia. Apesar de não existirem referências que nos permitam comprová-la, a hipótese de uma possível relação entre o topónimo Fradeira e o termos frade ou frater, em referência à presença do poder senhorial de Oia naquela localidade não nos parece de todo infundada.

${ }^{16}$ Como já referimos anteriormente, em contadas ocasiões Frei Bento de Segóvia fora substituído como procurador do mosteiro de Oia pelo abade Prudêncio de la Fuente. Vide nota n ${ }^{\circ} 13$.

17 Segue-se ao traslado desta procuração a declaração de Gaspar de Azevedo, tabelião público e judicial da vila de Caminha, datada de 2 de Dezembro de 1559, na qual reconhece como autêntico o sinal do escrivão de A Guarda, João da Igreja, que redigiu a dita procuração. AHN, Códices, L. 1037 , fols. 8 e 9.
} 
bens e propriedades lhe andam usurpadas e não saben suas demarcacões nen por onde parten e muitos dos foreiros the nom querem pagar seu foro ${ }^{18}$, o que se reflectia em muita perd $a^{19}$ para o mosteiro. Tal como teremos ocasião de analisar mais adiante, aquando do enquadramento deste tombo no contexto das reformas eclesiásticas, a origem destas perdas e usurpações remontam à época medieval. Usando estes argumentos, frei Bento de Segóvia pede a vosa alteza mande fazer tonbo das djtas teras e propriedades na forma acustumada ${ }^{20}$. Infelizmente, o que nos oferece a fonte não é sequer o traslado desta súplica do mosteiro, daí o facto de que este pequeno texto não esteja datado, nem se indique o tabelião que redigiu o dito pedido ou a localidade onde foi elaborado. Parece pois tratar-se de uma simples anotação que se limita a apresentar a parte do texto original que interessava então registar. Contudo, e apesar de desconhecermos a totalidade do teor deste pedido, contamos com um traslado mais detalhado (ou mesmo total) da provisão régia que lhe serviu de resposta.

Datada de 14 de Fevereiro de 1559, esta provisão começa com a expressão Eu El Rei faso saber ${ }^{21}$ e termina com o vocábulo Rainha ${ }^{22}$, a modo de assinatura pessoal. Debrucemo-nos brevemente sobre este detalhe, aparente sinal de incongruência por parte daquele que escreveu ou transcreveu este texto. $\mathrm{Na}$ nossa opinião, não se trata de um engano. Efectivamente, D. Sebastião tinha sido aclamado rei em 1557, o que se coaduna perfeitamente com o qualificativo utilizado no início deste documento. Contudo, o rei menino contava apenas três anos aquando da sua aclamação, o que explica a referência feita à rainha sua avó, $\mathrm{D}^{\mathrm{a}}$ Catarina, que assumiu a regência do reino entre 1557 e 1562, dada a evidente menoridade do monarca.

Este documento reveste-se de uma dupla importância no âmbito deste artigo e do projecto de tese que desenvolvemos. Em primeiro lugar, e ainda que de uma maneira muito pontual, é a expressão do contacto entre o cenóbio de Oia e a Coroa de Portugal. Por outro lado, cabe destacar a importância do conteúdo desta provisão régia no contexto da elaboração e organização do próprio tombo de propriedades da Granja da Silva.

A provisão de 1559, dirigida ao juiz de fora de Monção, contém as principais instruções que deverão presidir ao processo de inquérito. $\mathrm{O}$ cruzamento entre estas instruções e o conteúdo do próprio tombo revelam-nos que as primeiras foram seguidas de maneira rigorosa e estrita, verificando-se, em todo o momen-

\footnotetext{
${ }_{18}$ AHN, Códices, L.1037, fol. 3.

19 AHN, Códices, L.1037, fol. 3.

${ }^{20}$ AHN, Códices, L.1037, fol. 3.

21 AHN, Códices, L.1037, fol. 2.

${ }^{22}$ AHN, Códices, L.1037, fol. 3.
} 
to, uma correlação entre a descrição dos bens e propriedades da Granja da Silva e as indicações apresentadas nesta ordem régia. A nomeação da autoridade encarregue de dirigir a inquirição, o juramento prestado pelas testemunhas e foreiros interpelados, a averiguação das dimensões e consequente demarcação das propriedades, ou as indagações sobre rendas e foros, são algumas das informações presentes nesta provisão e, consequentemente, as bases da organização do conteúdo do tombo. $\mathrm{O}$ excerto que a seguir transcrevemos esclarece claramente estas normas:

Ey por bem e me praz que vos [juiz de fora de Monção] facaes demarcacão das teras e propiedades que diz que o esto mosteiro tem na granja da sillva termo da villa de valenca de minho posto que seja fora de vosa jurdicão [sic] pelo que vos mando que vades as ditas propiedades e cada hũa delas e levares com vos com hũ tabeliam dante vos com que fareis a esta demarcacão e sendo citadas e Reqerydas as partes a que toqar ouvyres sobre jso com ho procurador do esto mosteiro e vos enformareis dos lugares per onde as taes propiedades parten e confrontam asy per testemunhas antigas com juramento como per tonvos e escreturas se as ahi ouver e fareis logo mydir e demarcar per marcos e divisões aquellas cousas em que nom ouver duvyda e as partes foren contentes e no en que ouver duvyda determinares o que foi justiça dando apelação e agravo nos casos en que couber e compryr sea o que for determinado per maneira de que não aja apelacão e agravo e da demarcacão que asi fizerdes fareis fazer autos publicos pelo dito tabeliam con declaração das propiedades que foren e dos lugares en que estiverem e por quen parten e confrontam e das pessoas que as trazem e en quantas vjdas ou por quantos e dos foros e direitos que se delas pagam ao dito mosteiro ${ }^{23}$.

Finalmente, a última referência que precede o corpo do tombo propriamente dito, corresponde à nomeação de João da Barregã, lavrador e morador na freguesia da Silva, como responsável pela medição das propriedades da quintã da Fradeira, mediante indicação de frei Bento de Segóvia na sua qualidade de procurador do mosteiro de Oia.

${ }^{23}$ AHN, Códices, L.1037, fol. 2. 


\section{O Tombo da Granja da Silva de 1560/1565: conteúdo e contributos} para o estudo do PATRIMÓNio MEdieval de Oia no Entre-Lima-E-Minho

Tendo em conta que a principal finalidade deste texto é avaliar o contributo que nos pode oferecer uma fonte do século XVI no contexto de uma investigação centrada na época medieval, faremos apenas uma breve referência ao conteúdo do tombo, ou seja, à exaustiva descrição de cada uma das quatrocentas e vinte e cinco propriedades que abarca. Cerca de trinta casais ${ }^{24}$, distribuídos geograficamente pelas já citadas freguesias dos actuais concelhos de Valença e Vila Nova de Cerveira [Mapa 1], encabeçam a quase totalidade destas possessões. São na sua maioria parcelas dedicadas ao cultivo cerealífero, o que se reflecte claramente nos géneros usados no pagamento de quase todos os foros ${ }^{25}$, embora também encontremos, em muito menor número, referências ao cultivo da vinha, hortas e pomares, e ainda a elementos correspondentes à área de saltus, como por exemplo devesas e um pequeno monte ${ }^{26}$. Também estão presentes referências, ainda que escassas, a infra-estruturas de produção, nomeadamente um moinho e um lagar. O primeiro, descrito na fonte como "uma casa de moinhos com duas moendas", está situado acima da ponte de S. Pedro da Torre, integra o título das propriedades exploradas por João da Senra, morador em Santa Maria da Silva ${ }^{27}$. Trata-se de um meio de produção propriedade do mosteiro de Oia, pelo uso do

\footnotetext{
${ }^{24}$ Esta contabilização dos casais da Granja da Silva segue as indicações que nos proporcionam o corpo do tombo e o seu índice, isto é, apenas consideramos como casais os conjuntos organizados de propriedades que na própria fonte aparecem denominados como tal (casal). Existem também algumas propriedades que não surgem inseridas em nenhum casal.

$25 \mathrm{Na}$ esmagadora maioria dos casos contamos exclusivamente com informações referentes ao pagamento dos foros em géneros, sobretudo em cereal, a que muitas vezes se acrescentam uma ou duas galinhas. Os casos de rendas pagas em vinho são raros (AHN, Códices, L.1037, fols. 57 e 118), da mesma forma que os únicos pagamentos em dinheiro se associam a propriedades urbanas, nomeadamente a cinco casas localizadas em Valença (AHN, Códices, L.1037, fols. 148-162, 167168) e ao casal que traz Jordão Fernandes em Cerveira (AHN, Códices, L.1037, fols. 225-227). De referir também, pelo seu carácter excepcional, o pagamento de dois dias de jeira relativo ao casal da Cal, em S. Julião da Silva (AHN, Códices, L.1037, fols. 89-95).

26 Apuramos um total de quinze devesas, a maioria das quais povoadas por carvalhos (veja-se, a título de exemplo, AHN, Códices, L.1037, fols. 11, 13, 15, 27). Da mesma forma, o pequeno monte do Folhente, muito provavelmente localizado na freguesia de Santa Maria da Silva, incluía dentro dos seus limites dois carvalhos (AHN, Códices, L.1037, fol. 14). Note-se que as múltiplas referências a esta espécie vegetal parecem atestar a sua importância no quotidiano das populações rurais, nomeadamente ao nível da alimentação o que, e seguindo a opinião de André Marques, justificava na época medieval, e pelo que podemos conferir também no século XVI, a proximidade das zonas de plantação de carvalhos relativamente às áreas de cultivo, mais vigiadas e protegidas. André Marques, O casal. Uma unidade de organização social do espaço no Entre-Douro-e-Lima (906-1200), Noia, Editorial Toxosoutos, 2008, pág. 204.
}

27 AHN, Códices, L.1037, fol. 182. 
qual os foreiros estão obrigados a pagar seis alqueires de pão anuais, e ainda a moer a mesma quantidade de pão cada semana, "sem llevar maquja nenhũa"28. Porém, o mais salientável é o facto de este mesmo moinho, de acordo com as indicações presentes no tombo sobre a sua localização, parecer ser o mesmo que desde o ano de 1212 surge referido três vezes na documentação medieval de Oia.

Tal como temos vindo a assinalar desde o início, o objectivo central deste artigo não é o de proceder a uma análise exaustiva dos dados que nos fornece o tombo da Granja da Silva de 1560/1565 relativos às propriedades que incorpora. Pretendemos sim usá-lo como ferramenta para avaliar os factores preponderantes de um contexto evolutivo muito mais amplo. Começaremos, então, por tentar enquadrar este documento numa determinada dinâmica histórica que lhe é contemporânea, o que nos ajudará a compreender o porquê da sua elaboração. Seguidamente, procuraremos averiguar em que sentido a realidade reflectida no texto do tombo seiscentista da Granja da Silva, bem como os principais factores históricos que envolvem a sua execução, poderão contribuir para o estudo do conjunto patrimonial do mosteiro de Oia em Portugal na época medieval.

Sabemos de antemão que os trabalhos de inquérito e delimitação das propriedades da Granja da Silva datam de princípios da segunda metade do século XVI. Partindo deste pressuposto, tentaremos analisar os principais aspectos, nomeadamente políticos, que influenciaram a realidade do mosteiro de Oia, enquanto instituição religiosa e senhorial, nesta época. Na tentativa de esclarecer o porquê da elaboração deste tombo de propriedades, analisaremos alguns dos aspectos principais do papel da monarquia castelhana e espanhola nos esforços de reforma eclesiástica cujas consequências no mundo monástico se repercutem claramente neste documento.

Desde o reinado de João I de Castela, passando pelos Reis Católicos e afirmando-se definitivamente com Carlos V e Filipe II de Espanha, foram levadas a cabo várias tentativas de renovação eclesiástica, nomeadamente ao nível do clero regular. A alienação do poder e património monásticos, a ruína física, humana e material dos edifícios, aliados a um alto nível de indisciplina interna, conflitos de interesses e poderes paralelos no seio das ordens religiosas constituíram alguns dos principais problemas que, desde finais da Idade Média e num processo de evolução crescente, minavam vários mosteiros, incluído o de Oia. Neste contexto, os Reis Católicos inauguram um processo que levará a monarquia espanhola a assumir a liderança da reforma das ordens religiosas, a fim de conseguir travar este cenário de empobrecimento contínuo e de interferência dos poderes leigos no seio das instituições monásticas. O caso do monaquismo galego era, neste sentido, paradigmático, como o demonstram alguns dos principais temas

${ }^{28}$ AHN, Códices, L.1037, fol. 182. 
de debate abordados em 1478, durante o concílio nacional de Sevilha, liderado pelos próprios reis Fernando e Isabel. O estado de anarquia jurisdicional da Igreja, os privilégios e abusos dos clérigos, a falta de honestidade pública e privada dos religiosos, aliados às graves convulsões políticas que assolavam a Galiza, fizeram com que os esforços de renovação empreendidos tivessem em conta, desde o início, os mosteiros desta região ${ }^{29}$.

No caso particular da reforma dos cenóbios cistercienses, na qual se insere o mosteiro de Oia, os esforços empreendidos por Carlos V foram cruciais, no sentido de permitirem a consolidação definitiva do projecto de integração dos mosteiros cistercienses galegos na Congregação de Castela e a consequente adopção dos parâmetros da observância ${ }^{30}$. Este longo caminho em direcção à reforma das práticas e instituições monásticas do território galego só culminou em 1547, precisamente com a incorporação do mosteiro de Oia, cuja demora em adoptar os princípios e directrizes da observância impostos pela Congregação de Castela, se deveu, em grande parte, à resistência do seu último abade perpétuo, Gregório Neto. Tal fenómeno mereceu a nossa atenção pelo papel que, no decorrer dos acontecimentos, assumirá a Granja da Silva, bem como pelas referências directas a alguns dos intervenientes citados no tombo de 1560/1565.

Em Setembro 1523, pressionado pela comissão reformadora liderada por Afonso de Cisneros, o abade perpétuo do mosteiro de Oia, Gregório Neto, receando a perda dos privilégios que o seu cargo acarretava, abandona Oia na companhia do seu irmão, o prior João Rodrigues, e instala-se na Granja da Silva, levando consigo uma série de bens que ilegalmente subtraíra à comunidade, incluindo as reservas de pão e vinho e cem cabeças de gado. Perante tal acto de insubordinação, logo no mês seguinte, uma nova comissão de religiosos desta vez encabeçada pelo reformador Inácio de Collares deslocou-se ao mosteiro, destituindo formalmente Gregório Neto do cargo de abade que é, então, concedido a Lourenço Orozco, nomeado abade com o consentimento da comunidade. Não conformado com o que provavelmente interpretava como uma usurpação dos seus poderes, o abade deposto deixou o irmão à frente da Granja da Silva,

\footnotetext{
29 José García Oro, "Conventualismo y observancia. La reforma de las órdenes religiosas en los siglos XV y XVI", en José Luis González Novalín (dir.), La Iglesia en la España de los siglos XV y XVI, Tomo III- ${ }^{\circ}$ de Historia de la Iglesia en España, dir. de Ricardo GarCía-VILloslada, Madrid, Editorial Católica (Biblioteca de Autores Cristianos), 1980, págs. 268-269.

${ }^{30}$ Tal como sublinha M. Seijas Montero: La Observancia Cisterciense había llegado a Galicia en el reinado de los Reyes Católicos, pero el gran impulso de reforma monástica y de incorporación de los monasterios a la observancia pertenece, principalmente, al período de Carlos I. María SEIJAS Montero, Los cistercienses en el sudoeste de Galicia a fines del Antiguo Régimen, [CD ROM], Santiago de Compostela, Servizo de Publicacións da Universidade de Santiago de Compostela, [d.1. 2010], pág. 78.
} 
de alguma forma o bastião da sua resistência pessoal ao movimento da reforma observante, e partiu para Roma com o intuito de apelar directamente ao papa Clemente VII. Porém, antes de partir, e numa tentativa de legitimar o seu poder de abade, Gregório Neto forjou um documento no qual afora todos os bens da Granja da Silva a Gonçalo da Rocha, escudeiro de Caminha. No tombo da Granja da Silva de 1560 encontramos o que pensamos poder ser uma referência directa ao conteúdo deste documento aquando da descrição das propriedades da quintã da Fradeira trazidas por João da Senra, o Moço. Este foreiro afirma que as propriedades que traz, situadas na freguesia de Santa Maria da Silva e que pertencem ao mosteiro de Oia, lhe foram aforadas por Gonçalo da Rocha, "pesoidor que foi" da quintã da Fradeira ${ }^{31}$.

Apesar da reforma dos mosteiros cistercienses ser uma realidade e avançar a passo firme, o Papa Clemente VII manifestou claramente o seu apoio ao abade destituído, condenando explicitamente, não só o novo abade Lourenço de Orozco como também o próprio reformador Inácio de Collares, devolvendo assim o cargo a Gregório Neto.

Em 1528, durante o seu regresso de Roma, Gregório Neto morreu. Porém, o seu desaparecimento não bastou para dar lugar à definitiva integração de Oia no movimento da reforma observante. A clara oposição do Papa aos intentos de reforma e as relações e alianças estabelecidas por Gregório Neto com vários membros da nobreza, entre eles o já citado escudeiro Gonçalo Rocha, que durante quase vinte anos assumiram o controlo e posse do património do mosteiro de Oia, dificultaram grandemente a incorporação do cenóbio na Congregação do Cister espanhol. Finalmente, em Outubro de 1547, graças aos múltiplos esforços dos reformadores e do próprio monarca Carlos V no sentido de libertar o mosteiro do poder dos comendadores laicos, tem lugar a incorporação definitiva de Oia no movimento reformador da observância cisterciense ${ }^{32}$.

A união do mosteiro de Oia à Congregação de Castela representa o culminar dos esforços de renovação moral e institucional do clero regular na Galiza, ao qual se seguirá um período de recuperação, concretamente a nível económico, através, por exemplo, da organização do património e rendimentos dos vários mosteiros. Problemas como a asfixia económica imposta pelo poder leigo aos pequenos cenóbios, a degradação e ruína dos edifícios, a drástica diminuição do número de religiosos de alguns conventos, a desorganização da gestão patrimo-

\footnotetext{
31 AHN, Códices, L. 1037, fols. 55 e 56.

32 Sobre a questão do papel de Gregório Neto na resistência de Oia à integração no movimento da reforma observante veja-se: Fray María Damián YÁÑEz NEIRA, "El monasterio de Santa María de Oya y sus abades", El Museo de Pontevedra, XXVIII (1974), págs. 172-175 e M. CENDón FERnÁNDEZ, "Santa María de Oia"..., págs. 205-207.
} 
nial, revelada tantas vezes numa preocupante falta de actualização das rendas e foros e na falta de controlo dos tributos correspondentes às propriedades, exigiam uma resolução rápida e eficiente. Neste contexto, o tombo da Granja da Silva de 1560/1565 parece revelar-se como uma tentativa de resposta a alguns destes problemas. A criteriosa delimitação de todas as propriedades da Granja da Silva, a insistência nas referências a foros, prazos e rendas a pagar ou a enumeração de todos os foreiros, revelam uma preocupação concreta de apuramento dos benefícios que o património da Granja da Silva poderia representar no conjunto da economia do mosteiro.

A simples análise dos principais conteúdos do tombo de 1560/1565 permite-nos, assim, pensar que este documento é revelador de uma realidade concreta: a necessidade que um mosteiro, que acaba de submeter-se a um processo de renovação, tem de apurar de maneira minuciosa e concreta o número e situação geográfica das suas propriedades, bem como os rendimentos e efectivos humanos que lhe estão associados. Devemos, desta forma, enquadrar este documento no contexto das medidas levadas a cabo em consequência da reforma monástica que, durante os séculos XV e XVI ditou os destinos do clero regular galego e espanhol e que, por sua vez, representa o culminar dos vários e árduos esforços na tentativa de resolver os principais problemas que, desde finais da Idade Média, ameaçavam a sobrevivência de tantos cenóbios.

Apesar de, a priori, o contexto histórico e particularmente político espanhol ser o mais determinante no momento de compreender o porquê do inquérito efectuado em 1560 e 1565 às propriedades da Granja da Silva, não podemos olvidar o facto de que se encontravam em território português. Para além desta evidência, devemos ter em conta que o grande objectivo do texto que agora apresentamos e do projecto de investigação a que se subordina, é o de reflectir sobre o papel do mosteiro de Oia enquanto instituição senhorial transfronteiriça. Dada a importância da perspectiva comparativa entre o cenário português e o galego, pareceu-nos útil estabelecer um paralelismo entre o tombo da Granja da Silva e um documento similar correspondente a um mosteiro português, que apresenta uma série de analogias que poderão contribuir de maneira decisiva para a compreensão de determinados matizes da evolução da propriedade monástica em Portugal desde a Idade Média até à centúria de Quinhentos.

O estudo de Maria Helena da Cruz Coelho sobre o "tombo dos bees e propriadades e eramças" 33 do mosteiro de Tarouca, mandado elaborar por carta régia (tal como o tombo da Granja da Silva) a 13 de Abril de 1521, abre-nos

\footnotetext{
33 Maria Helena da Cruz Coelho, "S. João de Tarouca em tempos de Quinhentos", em Homens, espaços e poderes (Séculos XI-XVI), vol. II - Domínio Senhorial, Lisboa, Livros Horizonte, 1990, pág. 173.
} 
várias possibilidades de comparação e de enquadramento da realidade monástica do século XVI. Apesar de elaborado cerca de quarenta anos antes em relação ao da Granja da Silva, o tombo dos bens do mosteiro de Tarouca, abadia cisterciense tal como o mosteiro de Oia, oferece-nos uma perspectiva ad quem da evolução de um património monástico adquirido e consolidado durante a época medieval. À semelhança do que sucede no tombo da Granja da Silva, também no documento correspondente a S. João de Tarouca se vão descrevendo os bens do mosteiro, agrupados pelas diversas localidades em que se situam ${ }^{34}$, sendo igualmente muito concreto na enumeração dos prédios do mosteiro ${ }^{35}$, permitindo-nos através dele conhecer o alcance geográfico dos haveres de Tarouca e ainda percepcionar a variedade das propriedades que o mesmo detinha ${ }^{36}$.

Tratando-se em ambos os casos de tombos de propriedades, as semelhanças formais entre os dois códices são muitas, uma vez que o objectivo principal deste tipo de documentos era, precisamente, o de inventariar o número de propriedades pertencentes a um determinado senhorio, apurando dados como a sua dimensão, ou os foros e rendas que lhes correspondiam. Porém, no nosso caso concreto, o que nos interessa é estabelecer uma comparação entre os dois tombos, a fim de enquadrá-los numa realidade mais ampla, que nos é revelada, por exemplo, através das motivações que levaram à execução de ambos os tombos. Quando frei Bento de Segóvia, na qualidade de procurador do mosteiro de Oia, solicita ao rei de Portugal a autorização para iniciar os inquéritos aos foreiros da Granja da Silva, alega como justificações as já citadas faltas de pagamento das rendas por parte de alguns foreiros ou a usurpação de bens e propriedades, resultantes de uma delimitação deficiente ou mesmo inexistente, das propriedades. Os objectivos do mosteiro de Tarouca eram em tudo similares aos do mosteiro de Oia e a necessidade de um inquérito minucioso ao património monástico parece corresponder a motivações muito parecidas. $\mathrm{O}$ não pagamento das rendas está relacionado, na opinião de $\mathrm{M}^{\mathrm{a}}$ Helena $\mathrm{C}$. Coelho, com a sua desactualização e com a confusão que frequentemente existia entre os bens aforados e os dízimo a Deus que, ao estarem muitas vezes próximos geograficamente ou misturados entre si, dificultavam a sua identificação e dos correspondentes proprietários. No tombo da Granja da Silva encontramos múltiplas referências a parcelas dízimo a Deus inseridas em casais do mosteiro de Oia, algumas das quais de dimensões consideráveis, como é o caso da metade do casal de Vila Nova, em S. Julião da Silva, a que aludiremos mais adiante. No caso do tombo da Granja da Silva, a situação mais preocupante relativamente à falta de con-

\footnotetext{
34 Ma Helena da Cruz CoElho, "S. João de Tarouca...", pág. 176.

35 Ma Helena da Cruz CoElho, "S. João de Tarouca...”, pág. 174.

36 Ma Helena da Cruz Coelho, “S. João de Tarouca...”, pág. 174.
} 
trolo administrativo sobre as rendas e os foreiros parece ser a inexistência da carta de aforamento relativamente a vários bens. Dos trinta casais inventariados ao longo de todo o documento, sem contar as propriedades não encabeçadas, verificamos que em treze, os foreiros afirmam não possuir qualquer documento comprovativo. Noutros casos, afirmam ter conhecimento da existência do documento, não sabendo porém onde se encontra ou em que época havia sido concedido. Ora, esta situação, por um lado, é reveladora de uma longa tradição que, desde a época medieval, permitia ao mosteiro de Oia afirmar-se perante a população local como senhor e proprietário reconhecido da Granja da Silva, uma vez que a inexistência de um documento de aforamento relativamente a uma determinada propriedade não punha em causa o pagamento da renda correspondente por parte do foreiro. Contudo, por outro lado acarretava problemas de índole administrativa, como poderia ser a falta de actualização das rendas que refere $\mathrm{M}^{\mathrm{a}}$ Helena $\mathrm{C}$. Coelho para o caso de Tarouca. O caso de Isabel Garcia de Valença é, em nossa opinião uma expressão clara dessa conjuntura. Ao declarar os bens que trazia aforados do mosteiro de Oia nos arredores de Valença, Isabel Garcia afirmou não possuir qualquer documento, mas que no entanto ela e os seus antecessores pagavam à abadia 136 reais "de cem annos a esta parte" 37 . Se tomarmos este caso como exemplo, o que nos parece plausível dado o elevado número de propriedades sem contrato de aforamento, e mesmo tratando-se de uma estimativa temporal da própria interveniente, podemos pensar que algumas das rendas da Granja da Silva não foram alvo de actualização desde finais da época medieval.

O breve paralelismo que procuramos estabelecer entre os tombos de Tarouca (1521) e o da Granja da Silva (1560/1565) permitiu-nos perceber alguns dos contributos que a informação presente neste último poderia dar ao estudo da gestão patrimonial do núcleo de propriedades correspondentes durante a época medieval. Por um lado, as semelhanças formais entre os dois documentos revelam objectivos parecidos por parte dos dois mosteiros -Tarouca e Oia- no sentido de apurar uma série de propriedades e registar um conjunto de informações conducentes ao seu melhor aproveitamento económico. Por outro lado, determinados problemas, como a falta de actualização das rendas, eram reveladores de um panorama de desorganização que, originado na época medieval e agravado nos finais da mesma, se tentava solucionar no decurso do século XVI. Por fim, e relativamente ao caso do mosteiro de Oia, tentamos demonstrar que determinadas problemáticas decorrentes de uma falta de controlo sobre as propriedades não foram suficientes para romper os laços que uniam o mosteiro ao grupo dos dependentes do Entre-Lima-e-Minho português, que continuando a efectuar o

${ }^{37}$ AHN, Códices, L.1037, fol. 144. 
pagamento das rendas devidas ao cenóbio, mesmo sem a existência dos documentos de emprazamento que o legitimasse, revelavam um reconhecimento da autoridade senhorial de Oia, que logrou prolongar-se desde a época medieval até aos anos sessenta da centúria de Quinhentos.

\section{A ORGANIZAÇÃO DA PROPRIEDADE AGRÍCOLA E A PERMANÊNCIA DE UM} MODELO MEDIEVAL: O CASAL

No contexto da profunda investigação que desenvolveu sobre o casal, enquanto unidade de organização social do espaço no Entre-Douro-e-Lima do século X a inícios do XIII, André Marques afirma que, como tantas vezes acontece, os desenvolvimentos de um determinado fenómeno constituem a primeira das justificações para o seu estudo num momento anterior ${ }^{38}$. Tal afirmação é perfeitamente reveladora da finalidade deste artigo: a análise da informação presente num documento do século XVI como ponto de partida para a compreensão de um contexto histórico que lhe é precedente. Nesse sentido, o casal enquanto unidade de organização do espaço produtivo, social e fiscal, apresenta-se-nos como um excelente objecto de análise e reflexão pela importância de que se revestiu durante a Idade Média e ainda nos séculos seguintes ${ }^{39}$, comprovada aliás pelo destaque que assume ao longo de todo o documento.

O tombo da Granja da Silva de 1560/1565 revela-nos assim, como seria de esperar, uma herança medieval no que concerne à organização das diferentes parcelas da propriedade rural. O cruzamento dos dados procedentes do tombo com os que estão presentes nos documentos medievais relativos à Granja da Silva repercute claramente esta continuidade, como veremos mais adiante.

A origem do casal enquanto unidade tipo de exploração rural nasce no seio da villa altimedieval, um território bem delimitado, marco das actividades humanas relacionadas com a exploração da terra e a fixação dos homens no espaço rural ${ }^{40}$. O crescimento demográfico dos séculos XII e XIII provocou uma crescente e acentuada fragmentação da terra cultivada e consequente disseminação, por todo o Ocidente europeu, das parcelas de exploração agrícola de pequena e média

\footnotetext{
38 A. Marques, $O$ casal..., pág. 25.

39 Iria Gonçalves, O património do mosteiro de Alcobaça nos séculos XIV e XV. Lisboa, Universidade Nova de Lisboa, 1989, pág. 168.

$40 \quad M^{a}$ Carmen Pallares mendez e Ermelindo Portela silva, "Proyección territorial e influencia social de una institución monástica en la Edad Media: la abadía de Sobrado (952-1300)”, em Xesús Baloboa López e Herminia Pernas Orosa (eds.), Entre Nós. Estudios de Arte, Xeografía e Historia en homenaxe ó profesor Xosé Manuel Pose Antelo, Santiago de Compostela, Universidade de Santiago de Compostela, 2001, pág. 211.
} 
dimensão. Em determinadas regiões ${ }^{41}$, como é o caso do Noroeste da Península Ibérica, estas unidades de organização espacial receberiam o nome de casal.

O campo semântico que envolve o termo casal ${ }^{42}$ é vasto, e múltiplas as possibilidades de definir as realidades económicas e sociais que o vocábulo pode abranger e que, ao longo do tempo e do espaço, foram assumindo diferentes matizes. A heterogeneidade intrínseca ao conceito de casal é vital para compreender a existência de uma considerável variedade de definições propostas por vários investigadores. Contudo, e uma vez que uma enumeração exaustiva de todas as definições do termo casal não se enquadra nos objectivos deste texto, incidiremos apenas sobre aquelas que melhor se adequam à realidade da Granja da Silva exibida no tombo.

Iria Gonçalves, por exemplo, insiste na importância da casa, enquanto local de habitação e elemento de fixação do agregado familiar, em torno da qual se dispunham as dependências imediatas de apoio às actividades produtivas (currais, adegas, lagares, etc.) e as pequenas porções de terreno destinadas aos cultivos mais mimosos, como os pomares, hortas ou cortinhas ${ }^{43}$. A análise da informação contida no tombo da Granja da Silva permite-nos estabelecer um paralelismo bastante elucidativo entre as características dos casais referidos e a definição que acabamos de apresentar. São várias as indicações respeitantes às "casas de morada" e "cabeças de casal" 44 que confirmam a importância da moradia como centro das diversas parcelas e edifícios que constituem o casal. De facto, e tal como nos indica Maria Helena da Cruz Coelho, a preponderância da casa enquanto elemento aglutinador do casal era primordial, tanto desde o ponto de vista dos camponeses que em troca de certos pagamentos, dispunham de uma unidade de morada e terras de semeadura, garantes do sustento e permanência do agregado familiar, como do senhor para quem colocar a cabeça dentro das próprias terras poderia representar um incremento de ingressos pelo fogo

\footnotetext{
${ }^{41}$ Segundo A. Marques, a Itália e a região francesa da Gasconha constituem as outras duas zonas onde o casal se impôs como modelo de organização do espaço rural. A. MARQues, $O$ casal..., pág. 21.

42 Sobre o substantivo latino "casal" e a sua evolução etimológica e lexicológica no âmbito das regiões da Galiza e Norte de Portugal veja-se, por exemplo, Xaime Varela Sieiro, "Casal en la documentación altomedieval de Galicia: aproximación lexicográfica", em Actas do IV Congresso Internacional de Latim Medieval Hispânico (Lisboa, 12-15 de Outubro de 2005), Lisboa, Centro de Estudos Clássicos da Faculdade de Letras da Universidade de Lisboa, 2005, págs. 921-928; e A. MARQues, $O$ casal..., págs. 113-122.

${ }^{43}$ Iria Gonçalves, "Da estrutura do Casal nos fins da Idade Média", História e Crítica, no 7 (1981), pág. 61.

${ }^{44}$ Vejam-se, a título de exemplo, o casal da Vila (em Santa $M^{\text {a }}$ da Silva) que possui "cabeça de casal" e uma casinha velha construída pelos próprios foreiros, ou o casal de Vila Nova, em S. Julião, que incluía várias casas. AHN, Códices, L.1037, fols.57 e 99.
} 
em si e pelas dependências da exploração ${ }^{45}$. Contudo, as referências a casais que não incluem "casas de morada" são muito frequentes. Tal situação poderá estar relacionada, entre outras razões, com o incumprimento da cláusula de não pulverização dos direitos de usufruto e aforamento dos casais que se difunde, sobretudo a partir do século $\mathrm{XV}^{46}$. A recuperação demográfica que na centúria de Quatrocentos se começa a fazer sentir em algumas regiões deu origem a novos critérios na relação entre a terra e aqueles que a possuíam e trabalhavam. Multiplicam-se os herdeiros e os foreiros que cultivam as terras de um mesmo casal, e a casa que antes dominava o conjunto de propriedades perde o estatuto de centro aglutinador que, a partir de então, são trabalhadas pelos diferentes membros de uma mesma família ou, inclusivamente, por diferentes grupos familiares. Efectivamente, e de acordo com a opinião defendida por $\mathrm{M}^{\mathrm{a}}$ Helena $\mathrm{C}$. Coelho, a prática da divisão pelos vários herdeiros do aglomerado familiar era muito vincada e a multiplicidade de usufrutuários manifesta ${ }^{47}$.

Ainda no seguimento do fenómeno da multiplicidade de foreiros, decorrente do processo de fragmentação da propriedade, recorremos uma vez mais à comparação para tentar esclarecer aspectos da realidade retratada no tombo de 1560/1565. Ma Helena da Cruz Coelho revela-nos os seguintes dados relativos a dois casais pertencentes ao Cabido da Sé de Coimbra, nos finais da Idade Média

\begin{abstract}
(...) em Rio Frio do Mato um casal era habitado por 3 homens com as respectivas mulheres, mas repartido por 7 herdeiros que moravam fora dele, e outro era lavrado por um homem e sua mulher, mas mais de 4 outras pessoas nele tinham quinhões ${ }^{48}$.
\end{abstract}

O caso do casal de Rio Frio do Mato encontra paralelo em vários casais da Granja da Silva. A metade do casal de Vila Nova, por exemplo, situado em S. Julião da Silva, encontrava-se aforada em 1560, a Francisco de Gramil, o qual pagava de renda anual ao mosteiro de Oia quatro búzios de pão meado, pela medida velha, e uma galinha. Porém, e tal como no caso das propriedades da Sé de Coimbra, a informação do tombo revela a existência de outros foreiros, facto que se materializava numa divisão da metade do casal de Vila Nova em quatro

\footnotetext{
45 Maria Helena da Cruz Coelho, O baixo Mondego nos finais da Idade Média (Estudo de história Rural), vol. I, Coimbra, Faculdade de Letras, 1983, pág. 103-105.

46 M ${ }^{\mathrm{a}}$ H. da Cruz Coelho, O baixo Mondego..., pág. 99.

47 A autora chama também a atenção para o facto de que a realidade da fragmentação dos casais encontra-se frequentemente espelhada nos tombos de propriedades. $\mathrm{M}^{\mathrm{a}} \mathrm{H}$. da Cruz CoELHO, O baixo Mondego..., pág. 101.

48 Ma H. da Cruz Coelho, O baixo Mondego..., pág. 100.
} 
partes ou "títulos" de propriedades. João da Costa e sua cunhada Catarina Gonçalves traziam sete parcelas, Gregório Rosado quatro, Fernão Rodrigues três e o próprio Francisco Gramil doze parcelas. Sabemos também que pelo menos este último vivia fora do perímetro do casal, mais concretamente no lugar de Parada, freguesia de S. Miguel de Fontoura, situação análoga à do casal referido por $\mathbf{M}^{\mathrm{a}}$ Helena da Cruz Coelho. De acordo com o teor da declaração que faz Francisco de Gramil perante o juiz Tomé Álvares, responsável pelo inquérito aos bens da Granja da Silva, é ele o titular do foro desta propriedade, o que nos leva a pensar que talvez tenha subaforado algumas das parcelas aos lavradores anteriormente referidos. Esta situação parece corroborada pelo facto de, no conjunto dos pergaminhos medievais de Oia, a metade do casal de Vila Nova, ter sido aforada na sua totalidade a João de Gramil o Velho, por volta de 1493, e posteriormente, dois ou três anos mais tarde, aforada ao seu filho, Francisco de Gramil (provavelmente o pai daquele que em 1560 afirma ser o titular do foro). Ambos foram os únicos foreiros e, em nenhum dos documentos, existe referência a quaisquer outros intervenientes ${ }^{49}$. Ou seja, no caso do casal de Vila Nova, a multiplicação de foreiros aparece reflectida apenas no tombo de 1560, porém, o título de foro continua nas mãos de um membro da família que o detinha na época medieval, provavelmente a segunda voz do contrato.

Embora complexo, o caso do casal de Vila Nova deve ser entendido no contexto das transformações da organização dos espaço social e produtivo decorrentes da sua evolução ao longo do período medieval. A síntese feita por André Marques desta realidade parece-nos fulcral para a clarificação desta evolução, bem como para a percepção do território da Granja da Silva como resultado de um amplo e longo processo de transformações.

\section{É plausível que muitos dos casais que se documentam num determinado período tivessem sido criados num momento anterior elou continuassem}

\footnotetext{
${ }^{49}$ Os dois pergaminhos medievais que dão conta destes dois foros concedidos pelo mosteiro de Oia a João de Gramil o Velho e ao seu filho Francisco datam de 1493 e 1495, respectivamente, embora no tombo se especifique que o último contrato seria, em realidade, de 1497. Quer se trate de uma ou outra data, o tempo que separa este foro do depoimento de Francisco de Gramil aquando do inquérito de 1560 (aproximadamente 65 anos) leva-nos a pensar que se trata, não da mesma pessoa, mas sim, muito provavelmente, de familiares homónimos, talvez pai e filho. Parece-nos também importante ressalvar o facto de que os dois aforamentos de finais do século XV são praticamente iguais, mudando apenas o nome do foreiro. João e Francisco de Gramil aparecem referidos como as primeiras vozes nos dois contratos correspondentes (que teriam a duração de três vidas), exactamente, à mesma propriedade: a metade do casal de Vila Nova. Não sabemos que razões levaram o mosteiro a aforar a mesma propriedade ao pai e ao filho, com uma diferença de apenas dois ou quatro anos, porém, a morte do primeiro ou e a vontade do mosteiro de renovar o foro, tornando Francisco a primeira voz, apresentam-se como as hipóteses mais plausíveis. Ahn, Clero, Oya, carps. 1847 e 1849 , docs. 2 e 17.
} 
a existir, como unidades de povoamento, no $(s)$ período $(s)$ seguinte $(s)$. A comprová-lo parecem estar as menções documentais múltiplas a um mesmo casal, por vezes separadas por várias dezenas de anos, bem como as referências, num mesmo documento, a anteriores proprietários ou foreiros do casal, sobretudo nos casos em que se trata de familiares do "actual" proprietário, o que permite delinear genealogias que ultrapassam amiúde as duas gerações ${ }^{50}$.

Os elementos estruturais do casal - casas de habitação, terras de cultivo, infra-estruturas de produção e terrenos incultos - de forma mais ou menos directa e numerosa, estão presentes ao longo de toda a descrição das propriedades da Granja da Silva. Neste sentido, o tombo da Granja da Silva pode revelar-se de extrema utilidade, uma vez que a documentação medieval apenas nos dá uma visão parcial, aleatória e fragmentada do conjunto de propriedades da Granja da Silva. E, como já tivemos a oportunidade de referir, as várias semelhanças relativamente ao modelo medieval de casal, o seu comprovado prolongamento cronológico, a multiplicidade de referências cruzadas a topónimos e mesmo apelidos e famílias entre a documentação medieval e o tombo, fazem-nos pensar que o mapa de propriedades que este último nos faculta pode ser uma ferramenta muito útil aquando da necessidade de enquadrar geograficamente determinados terrenos ou analisar a sua evolução enquanto propriedade do mosteiro de Oia e objecto de contratos de aforamento.

Mais do que uma vez abordámos ao longo deste texto a questão da toponímia e o contributo que esta fonte do século XVI nos pode oferecer no sentido de tentar enquadrar geograficamente certas localidades e lugares referidos aleatoriamente e sem indicações específicas, ao longo da documentação medieval. Já vimos que o tombo de 1560/1565, pela minuciosidade da informação toponímica que revela, ajuda-nos a localizar com alguma exactidão vários dos casais e propriedades referidos desde a época medieval até aos princípios da segunda metade do século XVI, como são os casos do casal de Vila Nova ou do moinho de S. Pedro da Torre. Contudo, consideramos importante destacar outras duas unidades espaciais, as mais citadas ao longo de todo o Tombo, que correspondem a unidades territoriais mais amplas que o casal e com funções mais abrangentes no contexto da economia e gestão do património e produção agrícolas. Referimo-nos à granja da Silva e à quintã da Fradeira.

Inicialmente, a distinção entre uma e outra pode não ser fácil de estabelecer. O tombo de 1560/1565 é o dos bens e propriedades da Granja da Silva e ao longo das suas descrições elas surgem sempre referidas como parte integrante da quin-

50 A. MARQues, O casal..., pág. 71. 
tã da Fradeira. Sabemos que ainda hoje em dia o topónimo "Fradeira"51 dá nome a um dos lugares da freguesia de Santa Maria da Silva, aquela que pelo número de parcelas e casais que inclui segundo o próprio tombo seria a mais importante e central do conjunto das freguesias inseridas na Granja da Silva.

Ao longo dos textos preliminares, que antecedem a descrição das propriedades, a expressão "Granja da Silva" é utilizada em referência ao conjunto de propriedades que o mosteiro de Oia detinha na região abrangida pelas já mencionadas freguesias dos actuais concelhos de Valença e Vila Nova de Cerveira. Porém, no registo do inquérito feito aos foreiros e conseguinte descrição das propriedades, o designativo Granja da Silva desaparece sobressaindo unicamente o topónimo "quintã da Fradeira". Grande parte dos casais e propriedades são descritos como pertencentes à quintã da Fradeira do mosteiro de Oia, da mesma forma que se indica que nela se devem efectuar os pagamentos das rendas. Desta forma, parece-nos plausível e provável a hipótese que a quintã da Fradeira fosse o centro administrativo do grande conjunto ou núcleo de propriedades que era a Granja da Silva. Não existem vestígios físicos nem outras referências, mas é provável que o lugar da Fradeira da freguesia da Silva fosse o centro da gestão das propriedades, possuindo talvez o edifício, ou edifícios, necessários para a sua função de centro de recolha de rendas, quase todas em géneros, e habitação dos monges responsáveis por este trabalhos.

\section{Conclusão}

O espaço e o tempo, enquanto vectores fundamentais da História, servem também de fio condutor do texto que agora finaliza. Um espaço: o Entre-Limae-Minho, zona raiana onde o mosteiro de Oia, a partir do outro lado da fronteira, administrava o conjunto das propriedades que integravam a Granja da Silva. Um tempo, os anos de 1560 e 1565, datas concretas da elaboração de um documento em que ficou registada uma realidade que, como pudemos ver, ultrapassava os marcos dessa cronologia por ser o resultado da evolução de factores que nasceram e se desenvolveram num tempo bem mais remoto.

O tombo da Granja da Silva de 1560/1565 constituiu o objecto da nossa reflexão e a análise do seu valor enquanto terminus ad quem da evolução e consolidação do património medieval do mosteiro de Oia, o objectivo que procuramos alcançar.

O conjunto dos textos preliminares do tombo da Granja da Silva deu-nos uma série de pistas fundamentais para compreender o contexto em que se inseria o próprio documento. Os esforços renovadores empreendidos pelos Reis Católicos

\footnotetext{
51 Vide nota núm. 15.
} 
e continuados por Carlos V, saldaram-se numa série de reformas que afectaram a totalidade dos mosteiros galegos. Estas reformas foram, precisamente, a expressão da tentativa de resolução dos graves problemas que, desde a baixa Idade Média, punham em risco a própria sobrevivência de muitos cenóbios.

Posteriormente, e porque o mosteiro de Oia é, durante as épocas medieval e moderna, um senhor cujo poder e património ultrapassa a fronteira do rio Minho, recorremos à comparação. O estudo de Maria Helena da Cruz Coelho sobre S. João de Tarouca, permitiu-nos, por sua vez, obter uma percepção mais aproximada do contexto de renovação do clero regular e da preocupação e necessidade de apurar um património que urgia reorganizar em nome da rentabilidade e aproveitamento dos recursos que deveria proporcionar.

Finalmente, mantendo o enfoque na perspectiva evolutiva do conjunto da Granja da Silva desde o período medieval até ao século XVI, analisamos o casal, unidade base da organização social e produtiva do espaço rural. A riqueza das informações contidas no tombo da Granja da Silva facilitou, através do cruzamento de dados com a documentação medieval do mosteiro de Oia, a identificação de vários casais citados tanto na documentação medieval como no próprio tombo, possibilitando o estabelecimento de relações muito mais concretas entre o espaço da Granja da Silva nas épocas medieval e moderna.

O mosteiro de Santa Maria de Oia soube, ao longo de vários séculos, criar, incrementar e gerir um vasto património possuído no lado português da fronteira. O tombo dos bens e propriedades da Granja da Silva de 1560/1565 é, de alguma forma, o reflexo desse modelo de gestão patrimonial levada a cabo ao longo da época medieval e que, adaptando-se a todas as circunstâncias, tanto externas como endógenas, se procura manter na primeira centúria da Idade Moderna. 
MAPA 1 - Freguesias dos actuais concelhos de Valença do Minho e Vila Nova de Cerveira

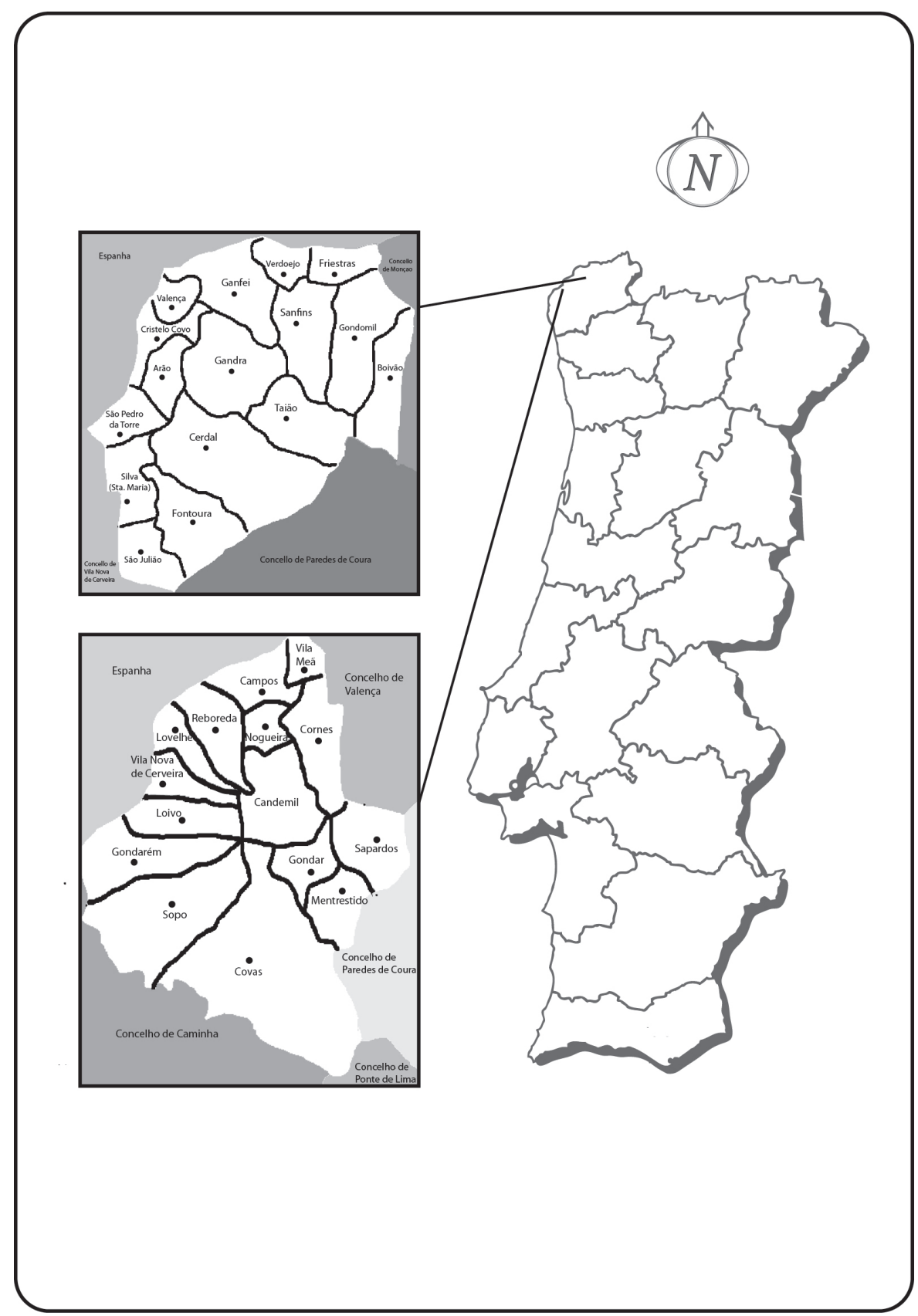




\section{BIBLIOGRAFIA}

Rodrigues, Ana Paula, O Tombo da Granja da Silva (1560/1565). Bases para uma análise da propriedade transfronteiriça do Mosteiro de Santa Maria de Oia. Traballo de Investigación Tutelado apresentado em Julho de 2010, na Facultade de Xeografía e Historia da USC. Inédito.

Andrade, Amélia Aguiar, "Entre Lima e Minho na Idade Média: uma relação de amor e ódio", em Carlos Alberto Ferreira de Almeida: in memoriam, vol. I, Porto, Faculdade de Letras da Universidade do Porto, 1999, págs. 77-92.

Cendón Fernández, Marta, “Santa María de Oia”, em Fray Ma Damián Yáñez Neira (coord.), Monasticón cisterciense gallego, vol. 1, León, 2000, págs. 198-223.

Coelho, Maria Helena da Cruz, O baixo Mondego nos finais da Idade Média (Estudo de história Rural), 2 vols., Coimbra, Faculdade de Letras, 1983.

Coelho, Maria Helena da Cruz, "S. João de Tarouca em tempos de Quinhentos”, em Homens, espaços e poderes (Séculos XI-XVI), vol. II - Domínio Senhorial, Lisboa, Livros Horizonte, 1990, págs. 173-220.

García Oro, José, “Conventualismo y observancia. La reforma de las órdenes religiosas en los siglos XV y XVI”, en José Luis González Novalín (dir.), La Iglesia en la España de los siglos XV y XVI, Tomo III- $1^{\circ}$ de Historia de la Iglesia en España, dir. de Ricardo GarcíaVilloslada, Madrid, Editorial Católica (Biblioteca de Autores Cristianos), 1980

Gonçalves, Iria, "Da estrutura do Casal nos fins da Idade Média”, História e Crítica, n 7 , 1981, págs. 60-72.

Gonçalves, Iria, O património do mosteiro de Alcobaça nos séculos XIV e XV. Lisboa, Universidade Nova de Lisboa, 1989.

Iglesias Almeida, Ernesto, O antiguo obispado de Tui en Portugal, Noia, Editorial Toxosoutos, 2009.

Marques, André Evangelista, $O$ casal. Uma unidade de organização social do espaço no Entre-Douro-e-Lima (906-1200), Noia, Editorial Toxosoutos, 2008.

Marques, José, "O mosteiro de Oia e a Granja da Silva, no contexto das relações luso-castelhanas dos séculos XIV-XV", em Relações entre Portugal e Castela nos finais da Idade Média, s. 1., Fundação Calouste Gulbenkian, Junta Nacional de Investigação Científica e Tecnológica, 1994, págs. 205-233.

Pallares Mendez, $\mathrm{M}^{\mathrm{a}}$ del Carmen e Portela Silva, Ermelindo, El Bajo Valle del Miño en los siglos XII y XIII. Economía agraria y estructura social, Santiago de Compostela, Universidade de Santiago de Compostela, 1971.

Pallares Mendez, Ma del Carmen e Portela Silva, Ermelindo, "Proyección territorial e influencia social de una institución monástica en la Edad Media: la abadía de Sobrado (9521300)", em Xesús Baloboa López e Herminia Pernas Orosa (eds.), Entre Nós. Estudios de Arte, Xeografía e Historia en homenaxe ó profesor Xosé Manuel Pose Antelo, Santiago de Compostela, Universidade de Santiago de Compostela, 2001, págs. 209-241.

Portela Silva, Ermelindo, "En torno a los orígenes del monasterio de Santa María de Oia. Císter en la frontera galaicoportuguesa.", em III Seminário Internacional Tarouca e Cister, Tarouca, 2010 (no prelo). 
Seijas Montero, María, Los cistercienses en el sudoeste de Galicia a fines del Antiguo Régimen, [CD ROM], Santiago de Compostela, Servizo de Publicacións da Universidade de Santiago de Compostela, [d.1. 2010].

Varela Sieiro, Xaime, "Casal en la documentación altomedieval de Galicia: aproximación lexicográfica", em Actas do IV Congresso Internacional de Latim Medieval Hispânico (Lisboa, 12-15 de Outubro de 2005), Lisboa, Centro de Estudos Clássicos da Faculdade de Letras da Universidade de Lisboa, 2005.

Yáñez Neira, Fray María Damián, "El monasterio de Santa María de Oya y sus abades", El Museo de Pontevedra, XXVIII, 1974, págs. 172-175. 